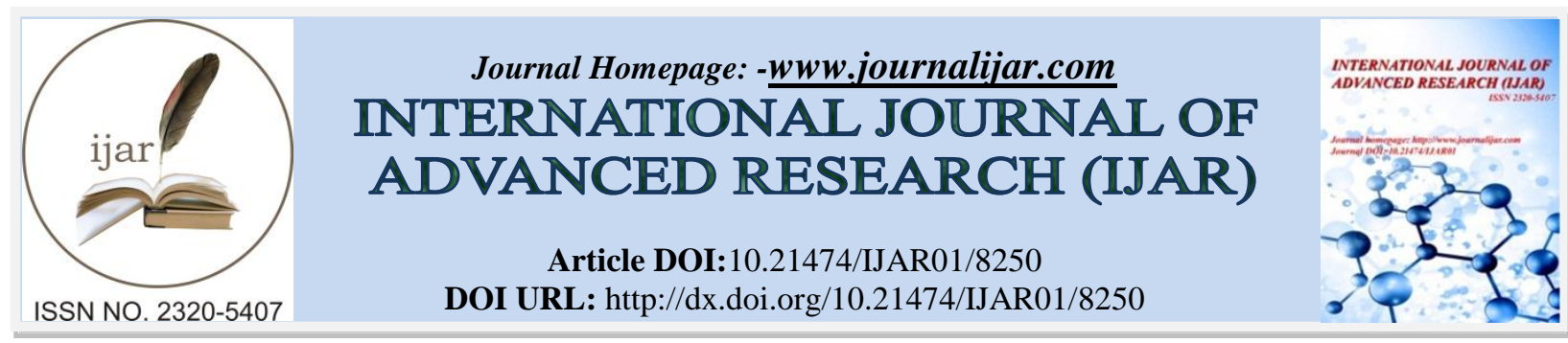

RESEARCH ARTICLE

\title{
CAMPUS SEXUAL ASSAULT AND THE LEGAL SOLUTION IN NIGERIAN UNIVERSITIES.
}

\author{
Akanle $^{1}$, Florence Foluso ${ }^{1}$, Ola TolulopeMonisola ${ }^{2}$, and Adewumi ${ }^{3}$. \\ 1. Department of Guidance and Counselling, Faculty of Education, University of Ado-Ekiti, Nigeria. \\ 2. Minnosota Population Centre,University of Minnosota, USA. \\ 3. Department of Social Science, Rufus Giwa Polytechnic, Owo, Ondo State.
}

\section{Manuscript Info}

Manuscript History

Received: 20 October 2018

Final Accepted: 22 November 2018

Published: December 2018

\begin{abstract}
This study investigates the extent and trend of campus sexual assault among undergraduates of tertiary institutions in Nigeria. Descriptive research design was used. The population consists of all female undergraduates in South West Geo-political Zoneof Nigeria. A sample of 500 female undergraduates was drawn using simple random sampling techniques. The findings revealed that campus sexual assault perpetrated by lecturers iscommon; unfortunately, sexual harassers often face little punishments from the schools' judicial systems, even when the perpetrator is not a first offender. The study recommendsthe legal solution to drastically reduced campus sexual assault, if its elimination will be possible in the short-time.
\end{abstract}

Copy Right, IJAR, 2018,. All rights reserved.

\section{Introduction:-}

Sexual harassment is a term used to describe behaviours such as a form of sexual coercion and exploitation that can be very stable, even confusing to identify and yet highly up-setting. These behavioursinclude but not limited to unwanted touch, unwanted sexual advances, suggestive, sexually motivated physical contact, request for sexual favours, or coercion of another person by another, particularly in the academic settings or the workplace. (Kelly, 2004). For many young women, the most common place where sexual coercion and harassment areexperienced is in schools or campuses. In an extreme case of violence in (1991),Perlez (1990) reported that 71 teenage girls were raped by their classmates and 19 others were killed at a boarding schoolin Meru Kenya. Research in Africa however, has highlighted the role of teachers in perpetrating sexual coercion. A report by Africa right by Ommar and Wael(1994)found cases of school teachers who gain sex in return for good grades or for not failing pupils in Democratic Republic of Congo, Ghana, Nigeria,Somalia, South Africa, Sudan Zambia and Zimbabwe.

Sexual harassment on college and University campus has become a major concern in recent years. Owuamanam (1995) reported a high prevalence of sexual coercion in public institutions in Nigeria Strongetal (2003) reported that $20 \%$ of graduate student and $19 \%$ of undergraduate student reported having been sexually harassed at school. Two major problems in dealing with issues of sexual harassment in college are gender differences in the level of tolerance and the attribution of blame. Women are often blamed for not taking a "compliment" and for provoking unwanted sexual attention by how they look and what they wear. Sexual harassment makes it difficult for students to study; others may worry about their grades. If the instructor controlling the grades is the harasser, students fear reporting the harassment. Some students use strategies such as avoiding the courses taught by the harasser or choosing another

Corresponding Author:-Akanle.

Address:-Department of Guidance and Counselling, Faculty of Education, University of Ado-Ekiti, Nigeria. 
adviser. In the extreme cases, the emotional consequences may be severe as for rape victims (Paludi, 1990) sexual harassment may affect people in many ways, directly or indirectly.

There are four main bases of complains about sexual harassment according to Sbrage and O'Donohue (2001) coercion and bribery is linked to the granting or denial of benefits. An example might be a professor suggesting to a student to comply or not to comply with his sexual overtures.This could affect the grades of the students. A hostile environment could be created and the environment is made uncomfortable because of unwanted sexual attention or repeated requests for dates. Other more aggressive acts such as sexual assaults, touching, folding, kissing might result. Finally other students who are legitimately working for their grades are unfairly affected while the student involved in a romantic relationship with the professor would be getting a better grade.Campus sexual assault or harassment is usually an imbalance of power in sexual harassment cases through which the offender tries to take the advantage of a victim.

Forcing students to have sexual activities is a behaviour found in every country. Campus sexual assault deals with the issue of power relations Among the pertinent issues that hinder responses to campus sexual assault or might prevent female students from refusing sexual advance, of teachers are: The victims lack choice or faces physical, psychological or social consequences if they refuse sexual advance from their lecturers. The relationship between students and lecturers involves power and struggle. A person having power over one limits one ability to refuse, sex for fear of repraisal, for example if a lecturer assisting one in a class ask one for a date, one is in an awkward position. If one says no, one's grade will suffer, one may be ignored in class and one may fail examination. Sexual harassment is a mixture of sex and power, power may often be a dormant element. In school, female students are devalued, by calling attention to their sexuality. Sexual harassment may be a way of keeping then "in place" and making them feel vulnerable (Akanle and Asebiomo (2012).The fact that sexual harasser often face little punishment from the judicial system in the school is also another factor that could hinder responses to campus sexual assault.In some cases repeated offenders often go free without town penalties like expulsion.

\section{Statement of the problem:-}

Campus sexual assault is one of the prevailing social problems and concern in the Nigerian Universities. Theproblem of sexual assault in the universities are so alarming that most universities have developed sexual harassment policy which prohibits sexual relationship between students and lecturers. A fundamental principlesof these policies is that student-lecturer relationship cannot be truly consensual, given the lecturers considerable power over the student academic standing and career plans. Though such policies help make student aware of sexual harassment issues; it seems many professors still get themselves into trouble with unintended subtle behaviourswhich have led to exploitation, sexual coercion, hostile environments or sexual harassment. There have been cases of other students been hurt in some ways by the relationship and hence some charges have been brought against some people. In order to prevent the danger of legal suits, also to allow personal privacy and freedom of legal adults to make choices about their relationship, as well as preventing imbalance of power and potential for sexual harassment, there is need for this study. Student found responsible for sexual assault on campus often face little or no punishment from school judicial systems, while their victims' lives are frequently turned upside down.According to a year-long investigation by the centre for public integrity (USA). Administrators believe the sections administered by the college judiciary system are thoughtful ways to hold abusive students accountable, but the center's probe have discovered that "responsible" findings rarely lead to tough punishments, like expulsion. Even in cases involving alleged repeated offenders, student found responsible for sexual assault face modest penalties while victimsare traumatized. Hence there is a need to investigate campus sexual assault so as to understand how universities deals with sexual assault allegations and be able to understand how counsellors and faculty members could end campus sexual assault in Nigeria. The follow general question are raised to guide the study.

1. Are students aware of campus sexual assault

2. What is the magnititude or pattern of campus sexual assault in Nigeria

3. How does the university administrators and counsellors handle campus sexual assault cases

4. How can we end campus sexual assault

The legal solution to campus sexual assault:-

A recent study commissioned by Action Aid international Nigeria (2004) "Violence Against Women and Access to Girl Child-Education in Nigeria", demonstrate that Violence Against Women and Access to Girl Child Education. Demonstrate that Campus Sexual Assault, other forms of sexual violence unlawful sex and sex with students even without their consent. Allegations of widespread sexual harassment of female students in Nigerian schools led the 
federal government to set up the committee on sexual Harassment in Educational Institutions in March 1989 (Action Aid, 2004). To be able to find solution, therefore, there is need for a legal and constitutional reform and a complete overhaul of the entire structure of the Nigerian Law if we are to expect any progress in the final solution to sexual assault crime in Nigeria.

It is imperative that Nigeria complies with and utilizes international norms and standard to draft/reform laws, police, and programs that address the linkage between violence and access to girl and child education. Translating laws and policies to programmes that respond to issues of sexual violence sexual rights and sexual health could be a major challenge and requires capacity building among students, staff as well as advocacy and programming efforts by the civil society.

Sexual health is a state of physical, emotional, mental and social well being related to sexuality. For sexual health to be attained and maintained, the sexual rights of students must be respected protected and fulfilled (WHO, 2002). Sexual rights embrace human rights that are already recognized in international laws. These include the right to respect for bodily integrity, right to consensual sex, the right to decide whether, when and whom to have sex with. Sexual assault is a violation of the sexual right of students. Finally, there is the need to hold the lecturers and other non teaching staff in the university accountable for respecting protecting and fulfilling the human rights in the context of campus sexual assault or any form of gender based violence in the universities.

\section{Methodology:-}

Descriptive research design was used for the study. The population consist of all female undergraduates in South West geopolitical zone of Nigeria. A sample of 500 female undergraduates students including teaching non teachingstaff were drawn using multistage sampling technique. Both qualitative and quantitative methods were used to gather the data. The research instrument for the qualitative data was a questionnaire, while focus group Discussions (FGDs) and in-depth interview(ID) was conducted for qualitative data. In order to find out issues with campus sexual assault the respondents were asked, whether they know what campus sexual assault is, if they hear of it, how often do people report cases of campus sexual assault, if they have ever been a target of campus sexual assault, do they think case, of such assault should be reported. They were also asked, if there are polices in their university against sexual assault, whem do students report to if they ever report. The students were also asked how their university treat cases of campus sexual assaults.

In order to find out which role the staff of faculty members play in the prevention of campus sexual assaults, faculty members were asked to tick $(\sqrt{ })$ the role the university staff play in the prevention of campus assaults. These roles include encouraging prevention programme, going lecture by experts on campus sexual assaults, making resources available for survivors of sexual assault and organizing public awareness such as film screening etc.

Frequency distribution and chi square were employed in the analysis of quantitative data while the quantitative data were analyzed using content analysis and ethnographic summaries.

\section{Results:-}

Question 1:-

Are students aware of campus sexual assault?

Table 1:-Awareness of students on campus sexual assault

\begin{tabular}{|c|c|c|c|c|c|}
\hline $\mathbf{S} / \mathbf{N}$ & ITEMS & RESPONSES & $\mathbf{F}$ & $\%$ & MEAN \\
\hline 1 & Do you know what campus sexual assault is? & $\begin{array}{l}\text { Yes I know } \\
\text { I don't know }\end{array}$ & $\begin{array}{l}456 \\
44\end{array}$ & $\begin{array}{l}91.2 \\
8.8 \\
\end{array}$ & 1.91 \\
\hline 2 & How often do you hear of campus sexual assaults & $\begin{array}{l}\text { Regularly } \\
\text { Not often }\end{array}$ & $\begin{array}{l}213 \\
287\end{array}$ & $\begin{array}{l}42.6 \\
57.4\end{array}$ & 1.43 \\
\hline 3 & $\begin{array}{l}\text { How often do people report cases as campus } \\
\text { sexual assault? }\end{array}$ & $\begin{array}{l}\text { Regularly } \\
\text { Not often }\end{array}$ & $\begin{array}{l}129 \\
317\end{array}$ & $\begin{array}{l}25.8 \\
74.2\end{array}$ & 1.26 \\
\hline
\end{tabular}

Table 1show that this implies that student were aware of sexual assaults while the frequency of occurrence and report of sexual assault cases were relatively low. 
Question 2:-

What is the magnitude of campus sexual assault in Nigerian universities?

Table 2:-Magnitude of campus sexual assault in Nigeria

\begin{tabular}{|c|c|c|c|c|c|c|c|}
\hline $\mathbf{S} / \mathbf{N}$ & ITEMS & YES & & NO & & MEAN & RANK \\
\hline & & $\mathrm{f}$ & $\%$ & $\mathrm{~F}$ & $\%$ & & \\
\hline 1 & Unwanted kiss & 134 & 26.8 & 366 & 73.2 & 1.27 & $5^{\text {th }}$ \\
\hline 2 & Unwanted sexual comments & 132 & 26.4 & 368 & 73.6 & 1.26 & $7^{\text {th }}$ \\
\hline 3 & Unwanted gesture & 263 & 52.6 & 237 & 47.4 & 1.53 & $1^{\mathrm{st}}$ \\
\hline 4 & Unwanted look & 240 & 48.0 & 260 & 52.0 & 1.48 & $2^{\text {nd }}$ \\
\hline 5 & Touched in a sexual way & 221 & 44.2 & 279 & 55.8 & 1.44 & $3^{\text {rd }}$ \\
\hline 6 & Grappled or pinched in a sexual way & 129 & 25.8 & 371 & 74.2 & 1.26 & $7^{\text {th }}$ \\
\hline 7 & Forced against your will to do something sexual & 197 & 39.4 & 303 & 60.6 & 1.13 & $13^{\text {th }}$ \\
\hline 8 & Unwanted sexual advances & 129 & 25.8 & 371 & 74.2 & 1.39 & $4^{\text {th }}$ \\
\hline 9 & $\begin{array}{l}\text { Shown picture of sexual dealings to encourage you to have } \\
\text { sex }\end{array}$ & 128 & 25.6 & 372 & 74.4 & 1.26 & $7^{\text {th }}$ \\
\hline 10 & Verbal threat related to sex & 87 & 17.4 & 413 & 82.6 & 1.26 & $7^{\text {th }}$ \\
\hline 11 & Touching of your breast or buttock when you don't want & 137 & 27.4 & 363 & 72.6 & 1.27 & $5^{\text {th }}$ \\
\hline 12 & Forced sex attempt & 110 & 22.0 & 390 & 78.0 & 1.22 & $11^{\text {th }}$ \\
\hline 13 & Forced to have sex & 68 & 13.6 & 432 & 86.4 & 1.14 & $12^{\text {th }}$ \\
\hline 14 & Experienced rape & 23 & 4.6 & 477 & 95.4 & 1.05 & $16^{\text {th }}$ \\
\hline 15 & Drugged or deceived into sex & 44 & 8.8 & 456 & 91.2 & 1.09 & $14^{\text {th }}$ \\
\hline 16 & Punished by an elderly person for refusing sex & 44 & 8.8 & 456 & 91.2 & 1.09 & $14^{\text {th }}$ \\
\hline
\end{tabular}

Table 2above reveals that ranking the experience of sexual assaults revealed that unwanted gesture was the most prominent. This was close followed by unwanted looked and touched in a sexual way while rape was the least in the ranking order.

\section{Question 3:-}

How do the University Administrators and Counsellors handle campus sexual assault cases?

Table 3:-Ways of handling campus sexual assault cases

\begin{tabular}{|c|c|c|c|c|c|c|}
\hline $\mathbf{S} / \mathbf{N}$ & ITEMS & \multicolumn{2}{|c|}{ YES } & \multicolumn{2}{|l|}{ NO } & \multirow[t]{2}{*}{ MEAN } \\
\hline & & f & $\%$ & $\mathrm{f}$ & $\%$ & \\
\hline 1 & Encouraging educational and prevention programme on campus & 21 & 4.2 & 479 & 95.8 & 1.04 \\
\hline 2 & $\begin{array}{l}\text { Bringing outside experts to campus to give lecture on sexual } \\
\text { assault prevention and speak on assault prevention }\end{array}$ & 134 & 26.8 & 366 & 73.2 & 1.27 \\
\hline 3 & $\begin{array}{l}\text { Faculty and staff training to make staff more responsive in } \\
\text { addressing them, on their role and responsibilities of students }\end{array}$ & 132 & 26.4 & 368 & 73.6 & 1.26 \\
\hline 4 & Disclose an assault either directly or indirectly & 263 & 52.6 & 237 & 47.4 & 1.53 \\
\hline 5 & $\begin{array}{l}\text { Ensuring that resources are made available for survivor of sexual } \\
\text { assault }\end{array}$ & 240 & 48.0 & 260 & 52.0 & 1.48 \\
\hline 6 & Organizing or participating in public awareness initiatives & 221 & 44.2 & 279 & 55.8 & 1.44 \\
\hline
\end{tabular}

Table 3 above presents ways university administrators and counsellors handle campus sexual assault cases. The result shows that the university administrators and counsellors ensured that resources are made available for survivor of sexual assault.

\section{Discussion:-}

The study has examined campus sexual assault and need to provide legal solution to the problem in Nigeria.Question one sought to find out whether students are aware of campus sexual assault. In analyzing this question, data on the responses of students concerned with the awareness of campus sexual assault among students were collected and analyzed using frequency counts and percentages. This findings is shown in table 1. The findings show that student are aware of campus sexual assault while the frequency of occurrence and report of campus sexual assault were relatively low. This finding support that of Owuamanam (1995) who observed a high prevalence of sexual coercion 
in public institution in Nigeria. The finding of the study also state that the frequency of reporting of campus sexual assault is low. The student may not report sexual assault because they lack choice or faces physical, psychological or social consequence if they refuse sexual advances from their lecturers. The relationship between students and lecturers involves power and struggle sex for fear of repraisal. This may also be the reason why student do not report sexual assault but prefer to avoid courses taught by the harasser. The findings concerned with the magnitude of campus sexual assault in Nigerian witnesses shows that unwanted gesture was more prominent, this was followed by unwanted look and touch in sexual ways while rape was the least in the ranking order.

Question three reveals how university administrators and counsellor handle campus sexual assault. An average number of administrators either disclose an assault either directly or indirectly, ensuring that resources are made available for surviour of sexual assault for treatment whole others prefer to organize public awareness initiative. It was observed that few counsellors or administrators do encourage educational prevention programme to prevent campus sexual assault or campus, while experts who could give lecturers on prevention of campus sexual assault from outside the campus are rarely brought. Lastly faculty and staff training needed to make staff responsive in addressing the prevention of campus sexual assault are not provided.

\section{Conclusion:-}

The major findings of this research shows that student do not report sexual assault cases. Another factor that may hinder responses to campus sexual assault in some cases is the fact that sexual harasser often face little punishment from the judicial system of the university. In some cases repeated offenders go free without penalities like expulsion. It is recommended that experts who would make student understand their right in relation to their personal safety concerning campus sexual assault like lawyers be invited to the school regularly to make student understand their sexual rights. Faculty and staff training which could make the staff responsive in addressing the issue of campus sexual assault needs to be regularly provided to the staff.

\section{References:-}

1. Akanle. F.T. (2008): "Sexual Abuse and Gender-Based Violence of Intimate Partners in Established Relationship"; International Journal of Sustainable Development (ICH). 8-16 Ghana.Akanle. F.T. (2011): "Sexual Coercion of Adolescent Girls in Yorubaland of Nigeria CurrentResearcher Journal of Social Sciences 3(2):132-138.

2. Akanle. F.F. (2011): “Sexual Coercion of a Development in Yorubaland of Nigeria;Current Research Journal of Social Science. 3(2): 132-138.

3. Akanle. F.T. (2012): "Sexual Abuse Among Female Secondary Students and Social Cultural Issues that Hinder or Enhance Responses to Child Sexual Abuse in Nigeria"; International proceeding of economics Development Research. Socially and Humality. (56) Kula LumpwMalaysia.

4. Akintoke A. (2006): "Domestic Violence in Ekiti State”;An unpublished Masters Project presentedto the Department of Guidance and Counselling, University of Ekiti State Nigeria. Fame. M.A. Central America: "The Cost of War and of Peace"; J Perspective, 8:14-15.

5. Jewkers R. Abrahams. V. (in press):“The Epidemiology of Raped and Sexual Coercion in South Africa - An Overview Social Science and Medicine"; (in press).

6. Kelly. G.F. (2004): "Sexuality Today"; The Human Perspective4th Edition McGraw hill Company, New York.

7. Longbap. N.P. (2012): "Engendering Family Security ThroughCounselling Strategies for Curbing Societal Violence”; Keynote and lead presentations at the Annual International Conference of the Counselling Association of Nigeria. $27-$ 29th August.

8. Omorodian.F.I, Olusanya. O, (1998):“The Social Context of Reported Rape in Benin City,Nigeria";African Journal of Reproductive Health 2:37-43.

9. Otive-Igbuzor. E. (2007): "Sexuality, Violence and HW/AIQS in Nigeria”; in Hymia Sexuality in Africa Beyond Reproduction Action Health Incorporated 2007 ISBN 978-1-920196-02-8.

10. Owuamanam D.O. (1995): "Youth the Age of Contrast in Human Development"; The $4^{\text {th }}$ Inaugural Lecture of Ondo State University, Ado-Ekiti, Nigeria, September, 1992.

11. Sunday ANI (2014): In Daily Son Tuesday, December16, 2014 p24 wwwsunnewsline.com.

12. United Nations ESCAP (2007):"Economic and Social Commission for Asia and the Pacific.A Report of the Expert Group Weting on the Regional Strategies for Implementation the Recommendations for the secretary. Generals IndeptStudys on all forms of Violence against women. United Nations conference Centre Bangkok, Thailand 26-27 April 2007.

13. Watts C et al. (1998): "Withholding Sex and Forced Sex: Dimension of Violence Against Zimbabwean Women"; Reproductive Health Matters, 6:57-65.

14. Watts; C and Zimmerman. C. (2002): "Violence Against Women: Global Scope and Magnitude" Loncet 359 (9313) (2002): 1233 . 